\title{
Penerapan Metode Analytical Hierarchy Process pada Rekomendasi Keputusan Pemilihan SIM Card Provider
}

\author{
Gde Brahupadhya Subiksa ${ }^{1}$, Lie Jasa ${ }^{2}$
}

\begin{abstract}
SIM card provider is the center of mobile telecommunication such as telephones, texting, Internet or Blackberry messenger. Lately, the SIM card business development is be marked more kinds of SIM card offered by the provider company with various brands, features and facilities. This causes consumers find it difficult to choose the SIM card that suits their needs such as the phone call need, texting need, Internet and Blackberry package, and bonus that the consumer wants.
\end{abstract}

From the problems above, consumer need a decision support system that can gives SIM card recommendation which suits the consumer's needs. The SIM card provider decision-making selection can be complex because of the multiple purposes of consumer. One of the tools that are suitable to use for SIM card sorting priority is Analytic Hierarchy Process (AHP) that is developed by Thomas L. Saaty.

The final result from this thesis is a system of SIM card provider selection decision-making support which suits with the consumer's needs. The system is tested with data collection by using questionnaire, which aims to obtain data that is more accurate about the usefulness of the system that has been created. Data collection are through the 30 respondents who tried the system from the user side and 5 respondents who filled out questionnaires from the administrator side. The results of the data collection and analysis of data collected declare that this system has its deficiency, especially the difficulty of priority weighting of both.

Intisari- Kartu perdana merupakan pusat dari telekomunikasi bergerak yang berupa telepon, SMS, internet maupun blackberry messenger. Berkembangnya bisnis kartu perdana akhir-akhir ini ditandai dengan semakin banyak dan beragamnya kartu perdana yang ditawarkan oleh perusahaan provider dengan bermacam merek, fitur dan fasilitas. Hal ini menyebabkan konsumen merasa kesulitan dalam memilih kartu perdana yang sesuai dengan kebutuhannya untuk telepon, SMS, paket internet, paket blackberry dan bonus yang diinginkan konsumen tersebut. Dari permasalahan di atas konsumen memerlukan suatu sistem pendukung pengambilan keputusan yang dapat memberikan rekomendasi kartu perdana yang sesuai dengan kebutuhan konsumen. Pengambilan keputusan pemilihan kartu perdana provider dapat menjadi kompleks karena adanya beberapa tujuan dari konsumen. Salah satu alat bantu yang cocok digunakan untuk pemilihan kartu perdana berdasarkan prioritas adalah Analytic Hierarchy Process (AHP) yang dikembangkan oleh Thomas L. Saaty.

\footnotetext{
Mahasiswa Pascasarjana, Teknik Elektro Fakultas Teknik Universitas Udayana, Jln. Kampus Bukit Jimbaran 80361 INDONESIA telp: 0361-703315; fax: 0361-703315; e-mail: brahupadhya@gmail.com

${ }^{2}$ Dosen, Jurusan Teknik Elektro Fakultas Teknik Universitas Udayana, Jln. Jalan Kampus Bukit Jimbaran 80361 INDONESIA telp:0361-703315; fax: 0361-703315; e-mail: liejasa@unud.ac.id
}

Hasil akhir dari pengumpulan data dan analisis data yang terkumpul menyatakan bahwa AHP dapat diterapkan dalam pemilihan kartu perdana provider. Dari hasil penelitian ini diharapkan developer atau pengembang sistem lain dapat memaksimalkan sistem pendukung pengambilan keputusan yang mereka buat atau mereka kembangkan.

Kata Kunci- AHP, DSS, SPK, Likert, Usability.

\section{PENDAHULUAN}

Sistem Pendukung Pengambilan Keputusan (SPPK) atau Decision Support Sistem (DSS) merupakan suatu sistem yang interaktif, yang membantu pengambil keputusan melalui penggunaan data dan model-model keputusan untuk memecahkan masalah yang sifatnya semi terstruktur. Sedangkan menurut jurnal Khoiruddin menyebutkan bahwa Finlay mendefinisikan Sistem Pendukung Pengambilan Keputusan secara longgar dengan menyatakannya sebagai "sistem berbasis komputer yang dapat membantu proses pengambilan keputusan". Sistem pendukung pengambilan keputusan dapat menghasilkan solusi dengan lebih cepat serta hasilnya dapat diandalkan.

Permasalahan pengambilan keputusan dapat menjadi kompleks karena adanya pelibatan beberapa tujuan maupun kriteria. Salah satu alat bantu yang cocok digunakan untuk pemilihan kandidat atau pengurutan prioritas adalah Analytic Hierarchy Process (AHP) yang dikembangkan oleh Thomas L. Saaty. Menurut Saaty (1993), hirarki didefinisikan sebagai suatu representasi dari sebuah permasalahan yang kompleks dalam suatu struktur multilevel dimana level pertama adalah tujuan, yang diikuti level faktor, kriteria, sub kriteria, dan seterusnya ke bawah hingga level terakhir dari alternatif [1].

Kartu perdana merupakan sebuah produk yang sangat penting bagi para pengguna telepon seluler (handphone) ataupun internet modem (Yusuf). Sedangkan menurut Wisegeek (2007) kartu perdana adalah sebuah komponen chip memory yang digunakan pada sebuah telepon seluler (handphone) [2]. Tentu saja saat ini hampir seluruh masyarakat Indonesia menggunakan teknologi ini baik pada handphone, modem ataupun tablet mereka dengan beragam jenis kartu perdana dan kebutuhannya. Berkembangnya bisnis kartu perdana akhir-akhir ini menunjukan suatu gejala, yaitu semakin banyak dan beragamnya kartu perdana yang ditawarkan oleh perusahaan provider dengan bermacam merek, fitur dan fasilitas yang semakin lengkap dan bonus yang diberikan. Hal tersebut menyebabkan konsumen merasa kesulitan dalam memilih kartu perdana yang sesuai dengan kebutuhannya.

Tentu saja penerapan metode AHP pada rekomendasi pemilihan kartu perdasana provider ini dapat membantu atau memberikan rekomendasi kartu perdana yang sesuai dengan 
kebutuhan penggunanya dan dengan adanya penelitian ini untuk membuktikan apakah pemilihan kartu perdana provider dapat didukung dengan sistem pendukung pengambilan keputusan.

\section{Tinjauan Metode}

Sistem Pendukung Pengambilan Keputusan (SPPK) atau Decision Support Sistem (DSS) merupakan suatu sistem yang interaktif, yang membantu pengambil keputusan melalui penggunaan data dan model-model keputusan untuk memecahkan masalah yang sifatnya semi terstruktur [3]. Dapat juga dikatakan sebagai sistem komputer yang mengolah data menjadi informasi untuk mengambil keputusan dari masalah yang spesifik. Menurut Moore dan Chang, sistem pendukung pengambilan keputusan dapat digambarkan sebagai sistem yang berkemampuan mendukung analisis data, dan pemodelan keputusan, berorientasi keputusan, orientasi perencanaan masa depan, dan digunakan pada saat-saat yang tidak biasa [4]. Metode yang memiliki akurasi yang cukup tinggi pada penetuan pengambilan keputusan adalah Analytic Hierarchy Process (AHP) merupakan suatu model pendukung keputusan yang dikembangkan oleh Thomas L. Saaty. Menurut Saaty, hirarki didefinisikan sebagai suatu representasi dari sebuah permasalahan yang kompleks dalam suatu struktur multilevel dimana level pertama adalah tujuan, yang diikuti level faktor, kriteria, sub kriteria, dan seterusnya ke bawah hingga level terakhir dari alternative [5]. Suatu masalah yang kompleks dapat diuraikan ke dalam kelompokkelompoknya yang kemudian diatur menjadi suatu bentuk hirarki sehingga permasalahan akan tampak lebih terstruktur dan sistematis [6].

AHP sering digunakan sebagai metode pemecahan masalah dibanding dengan metode yang lain karena alasanalasan sebagai berikut:

1 Struktur yang berhirarki, sebagai konsekuesi dari kriteria yang dipilih, sampai pada sub kriteria yang paling dalam.

2 Memperhitungkan validitas sampai dengan batas toleransi inkonsistensi berbagai kriteria dan alternatif yang dipilih oleh pengambil keputusan.

3 Memperhitungkan daya tahan output analisis sensitivitas pengambilan keputusan.

Dalam pengujian metode mempergunakan blackbox test dengan mempergunakan metode Jacob Nielson untuk menguji kepuasaan pengguna dan kebergunaan system [7]. Pengambilan data pengujian mempergunakan kuesioner yang pernyataannya disusun berdasarkan metode yang dikembangkan Jacob Nielson dan dipadukan dengan penilaian atau penentuan skala dengan Likert yang dibagi menjadi 5 kategori, dengan nilai terendah sangat tidak setuju dan nilai tertinggi sangat setuju.

\section{HASIL DAN PEMBAHASAN}

\section{A. Implementasi AHP}

Halaman input bobot adalah halaman untuk pengunjung yang ingin memilih kartu perdana yang sesuai dengan kebutuhannya, nilai sangat-sangat penting adalah kebutuhan yang paling penting atau diprioritaskan diantara kriteria yang lainnya.
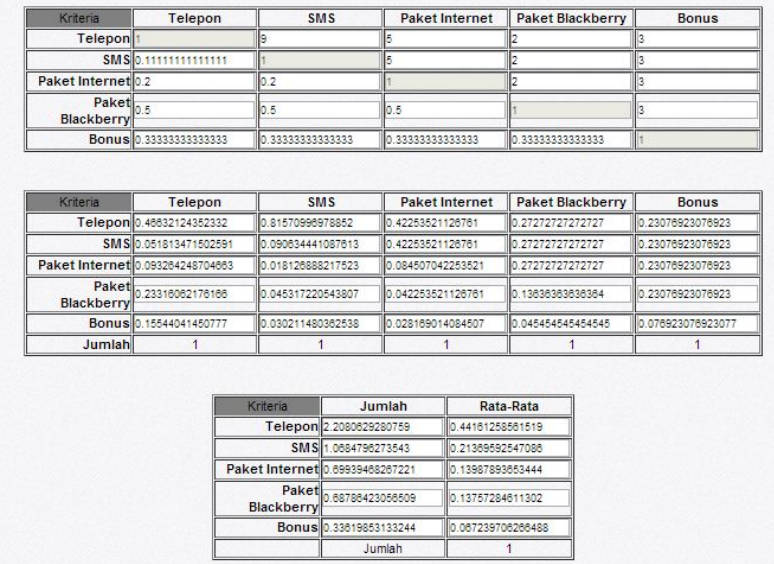

Gambar 1. Halaman Proses Perhitungan

Halaman proses perhitungan ini menunjukan perhitungan sesuai dengan masukan bobot sebelumnya. Pada halaman ini pengguna dapat memilih jumlah rekomendasi yang ingin ditampilkan.

\begin{tabular}{|c|c|c|}
\hline $\begin{array}{c}\text { No } \\
\text { Rekomendasi }\end{array}$ & Rekomendasi Kartu & Detail Kartu \\
\hline \hline 1 & axis & Lihat Rincian Kartu \\
\hline \hline 2 & $\mathbf{3}$ & Lihat Rincian Kartu \\
\hline \hline 3 & aha & Lihat Rincian Kartu \\
\hline \hline 4 & flexi & Lihat Rincian Kartu \\
\hline \hline 5 & smartfriend & Lihat Rincian Kartu \\
\hline \hline 6 & xl & Lihat Rincian Kartu \\
\hline \hline 7 & simpati & Lihat Rincian Kartu \\
\hline \hline 8 & esia & Lihat Rincian Kartu \\
\hline \hline 9 & as & Lihat Rincian Kartu \\
\hline \hline 10 & im3 & Lihat Rincian Kartu \\
\hline \hline \multicolumn{2}{|c|}{} & Silahkan Isi Kuesioner Anda ! \\
\hline
\end{tabular}

Gambar 2. Halaman Rekomendasi Kartu Perdana

Halaman rekomedasi kartu perdana menunjukan hasil yang sesuai dengan perhitungan proses sebelumnya, di halaman ini juga memperlihatkan nilai tertinggi yang berarti kartu yang sesuai dan direkomendasikan untuk pengguna sistem tersebut.

\section{B. Pengujian Kebergunaan}

Pengujian sistem ini membahas mengenai pengujian sistem yang telah diimplementasikan, dengan cara menguji sistem dengan data primer yaitu kuesioner yang diisi oleh 30 orang responden sebagai pengguna sistem, untuk mengetahui efektifitas penggunaan sistem pendukung pengambilan keputusan pemilihan kartu perdana provider yang sesuai dengan kebutuhan penggunannya. Kriteria responden adalah

Pernyataan-pernyataan pada kuesioner mengandung lima aspek usabitity Jacob Nielson yaitu Learnability, Efficiency, Memorability, Errors, dan Satisfaction. Maka tabel pernyataan tersebut seperti di bawah ini : 
TABEL I

\begin{tabular}{|c|c|}
\hline & \\
\hline & Pernyataan \\
\hline & $\begin{array}{l}\text { Tampilan awal sistem ahp kartu perdana dapat } \\
\text { dikenali dengan mudah. }\end{array}$ \\
\hline & $\begin{array}{l}\text { Anda dapat menemukan kartu perdana yang anda } \\
\text { inginkan dengan mudah. }\end{array}$ \\
\hline & $\begin{array}{l}\text { Anda dapat dengan mudah mengisi nilai kriteria sesuai } \\
\text { dengan kebutuhan anda. }\end{array}$ \\
\hline & $\begin{array}{l}\text { Hasil rekomendasi oleh sistem dapat anda lihat rincian } \\
\text { tarifnya dengan mudah dan lengkap. }\end{array}$ \\
\hline & $\begin{array}{l}\text { Huruf-huruf yang ditampilkan sistem ahp kartu } \\
\text { perdana mudah terlihat dan terbaca. }\end{array}$ \\
\hline & $\begin{array}{l}\text { Simbol dan gambar pada sistem ahp kartu perdana } \\
\text { mudah dipahami. }\end{array}$ \\
\hline & $\begin{array}{l}\text { Desain warna web sistem ahp kartu perdana nyaman } \\
\text { dilihat. }\end{array}$ \\
\hline & $\begin{array}{l}\text { Bahasa yang ditampilkan sistem ahp kartu perdana } \\
\text { mudah dimengerti. }\end{array}$ \\
\hline & $\begin{array}{l}\text { Anda dapat dengan mudah mengerti setiap halaman } \\
\text { sistem ahp kartu perdana }\end{array}$ \\
\hline & \\
\hline
\end{tabular}

Pemberian nilai pada setiap pernyataan mempergunakan kategori yang memiliki skornya masingmasing yaitu :

TABEL II

SKOR KATEGORI SKALA LIKERT

\begin{tabular}{|c|c|c|}
\hline Kategori & Skor & Total Nilai \\
\hline Sangat Tidak Setuju (STS) & 1 & $0-20$ \\
\hline Tidak Setuju (TS) & 2 & $21-40$ \\
\hline Netral/Ragu-ragu (R) & 3 & $41-60$ \\
\hline Setuju (S) & 4 & $61-80$ \\
\hline Sangat Setuju (SS) & 5 & $81-100$ \\
\hline
\end{tabular}

Setelah dilakukan penyebaran kuisioner yang diberikan pada responden, maka selanjutnya dilakukan rekap terhadap hasil kuisioner yang telah dikumpulkan. Total nilai dari 30 responden dan dicari jenis kategorinya berdasarkan skala likert pada Tabel II.

Langkah pertama adalah mencari skor terkecil (xMin), yaitu jumlah pernyataan dikalikan dengan nilai jawaban terkecil dan dikalikan jumlah responden sehingga $\mathrm{xMin}=10 \mathrm{x}$ $1 \times 30=300$. Kemudian untuk skor terbesar (xMax) didapat dengan jumlah pernyataan dikalikan nilai jawaban terbesar dan dikalikan dengan jumlah responden sehingga $\mathrm{xMax}=10$ x 5 x $30=1500$. Berdasarkan hasil diatas maka akan diketahui total nilai seluruh responden berada antara $\mathrm{xMin}=300$ sampai $\mathrm{xMax}=1500$ Kemudian dicari total nilai seluruh responden dengan tabel di bawah ini :

TABEL III

PERHITUNGAN KUESIONER PENGGUNA SISTEM

\begin{tabular}{|l|l|l|l|l|l|}
\hline \multirow{2}{*}{ No } & \multicolumn{5}{|c|}{ Jumlah Tanggapan } \\
\cline { 2 - 6 } & STS & TS & R & S & SS \\
\hline 1 & 0 & 0 & 1 & 20 & 9 \\
\hline 2 & 0 & 0 & 1 & 16 & 13 \\
\hline 3 & 1 & 2 & 1 & 15 & 11 \\
\hline 4 & 0 & 0 & 2 & 17 & 11 \\
\hline 5 & 0 & 0 & 0 & 14 & 16 \\
\hline
\end{tabular}

Gde Brahupadhya Subiksa: Penerapan Metode Analytic Hierarchy ...

\begin{tabular}{|c|l|l|l|l|l|}
\hline 6 & 0 & 1 & 1 & 15 & 13 \\
\hline 7 & 0 & 0 & 1 & 15 & 14 \\
\hline 8 & 0 & 0 & 2 & 17 & 11 \\
\hline 9 & 0 & 2 & 0 & 17 & 11 \\
\hline 10 & 0 & 1 & 3 & 14 & 12 \\
\hline Total & $\mathbf{1}$ & $\mathbf{6}$ & $\mathbf{1 2}$ & $\mathbf{1 6 0}$ & $\mathbf{1 2 1}$ \\
\hline
\end{tabular}

TABEL IV

TOTAL SELURUH RESPONDEN (PENGGUNA SISTEM)

\begin{tabular}{|c|r|r|}
\hline Skor & \multicolumn{1}{|c|}{$\begin{array}{c}\text { Total } \\
\text { Pernyataan }\end{array}$} & $\begin{array}{c}\text { Hasil } \\
\text { (Skor x Total Pernyataan) }\end{array}$ \\
\hline 1 & 1 & 12 \\
\hline 2 & 6 & 36 \\
\hline 3 & 12 & 640 \\
\hline 4 & 160 & 605 \\
\hline 5 & 121 & $\mathbf{1 2 9 4}$ \\
\hline \multicolumn{3}{r|}{} \\
\hline
\end{tabular}

$$
\begin{aligned}
& \text { Persentase skala likert }=\frac{\text { Total }}{x M a x} \times 100 \%= \\
& \text { Persentase skala likert }=\frac{1294}{1500} \times 100 \%=\mathbf{8 6 , 2 7 \%}
\end{aligned}
$$

\section{Persentase skala likert $=\mathbf{8 6 , 2 7} \%$}

Berdasarkan hasil persentase perhitungan skala likert di atas didapat total nilai keseluruhan sebesar $86,27 \%$ dari total 30 responden. Menurut tabel skala likert nilai 86,27\% termasuk kedalam kategori sangat setuju. Sehingga dapat disimpulkan bahwa usability halaman pengguna memiliki usability yang sangat mudah dipergunakan oleh pengunjung atau pengguna sistem pendukung pengambilan keputusan pemilihan kartu perdana tersebut.

Jika berdasarkan hasil kuesioner menurut usability yang didefinisikan sebagai ukuran kualitas pengalaman pengguna ketika berinteraksi dengan produk atau sistem. Sehingga jikadianalisis dari lima apek usability menurut Jacob Nielson menjadi :

\section{a. Learnability}

Pernyataan kuesioner learnability yang terdapat pada pernyataan nomor 1,3 dan 4, learnability menjelaskan tingkat kemudahan pengguna atau pengunjung untuk menyelesaikan task-task dasar ketika pertama kali mereka melihat atau berhadapan dengan sistem yang ada. Pada pernyataan nomor 1 dan nomor 4 didominasi oleh responden yang menyatakan setuju mengenai kemudahan mengenali tampilan awal website dan mudahnya pengguna sistem melihat tarif kartu perdana. Tetapi untuk pernyataan nomor 3 tentang kemudahan mengisi nilai kriteria ada 3 orang responden yang tidak setuju, ini dikarenakan responden atau pengguna yang baru menggunakan sistem tidak mengerti mengenai pembobotan kriteria yang sesuai dengan kebutuhannya.

\section{b. Efficiency}

Pernyataan kuesioner efficiency yang terdapat pada pernyataan nomor 2, 3, 4 dan 9, menjelaskan seberapa cepat pengguna dapat menyelesaikan tugas-tugas yang ada saat mereka pertama kali menggunakan sistem. 4 orang p-ISSN:1693 - 2951; e-ISSN: 2503-2372 
responden menyatakan tidak setuju terhadap pernyataan nomor 4 dan 9 karena responden yang baru menggunakan sistem tidak dapat dengan cepat menyelesaikan tugas pembobotan kriteria kebutuhannya dan tidak mengerti fungsi halaman proses perhitungan pembobotan.

\section{c. Memorability}

Pernyataan kuesioner memorability yang terdapat pada pernyataan nomor 2, 3 dan 10, menjelaskan tetang tingkat kemudahan pengguna atau pengunjung dalam menggunakan sistem dengan baik, setelah beberapa lama tidak menggunakannya. Pada pernyataan nomor 3 mengenai kemudahan pembobotan kriteria kebutuhan pengguna, 2 orang responden menyatakan tidak setuju karena pembobotan kriteria sesuai dengan kebutuhan pengguna dianggap sulit walaupun pengguna pernah menggunakan sistem tersebut sebelumya. Sedangkan untuk pernyataan nomor 2 dan 10, beberapa responden menyatakan ragu-ragu dalam menemukan kartu perdana yang diinginkan dengan mudah dan dapat mengingat kembali tampilan dan fitur-fitur yang tersedia pada sistem.

\section{d. Errors}

Pernyataan kuesioner errors yang terdapat pada pernyataan nomor 3, 5, 6, dan 8. Errors menjelaskan kemungkinan terjadinya errors atau kesalahan yang dilakukan oleh pengguna dan seberapa mudah mereka dapat mengatasinya. Pada pernyataan nomor 3 beberapa responden menyatakan tidak setuju karena responden merasa kesulitan saat terjadi errors pada pembobotan dan perhitungan kriteria kebutuhan penggunannya. Sedangkan pada pernyataan nomor 5, 6 dan 8 didominasi dengan jawaban setuju karena responden dapat dengan mudah mengatasi kesalahan yang mereka lakukan, seperti salah membaca tulisan, salah membaca simbol atau gambar, dan salah mengerti kata-kata yang ditampilkan oleh sistem.

\section{e. Satisfaction}

Pernyataan kuesioner satisfaction yang terdapat pada semua pernyataan di kuesioner. Satisfaction menjelaskan tentang tingkat kepuasan pengguna dalam menggunakan sistem yang telah dibuat. Jika dilihat dari hasil jawaban responden kuesioner dan analisis 4 aspek usability di atas menyatakan terjadi ke tidak puasan pengguna sistem atau responden pada pernyataan nomor 3 mengenai kemudahan dalam pembobotan kriteria kebutuhan.

\section{KESIMPULAN}

Melalui hasil penelitian penerapan metode AHP pada pemilihan kartu perdana provider yang dibandingkan dengan perhitungan AHP secara manual dan analisis data yang diperoleh dari kuesioner yang diisi 30 orang responden yang mencoba sistem pengguna. Sehingga kesimpulan yang dapat diambil dari penelitian ini adalah:

1. Metode AHP yang diimplementasikan pada sistem dapat menghasilkan rekomendasi kartu perdana provider yang sesuai dengan kebutuhan penggunannya.

2. Metode AHP dapat membantu dan mempermudah penggunanya dalam menentukan kartu perdana provider.

3. Dalam membangun sistem dengan penerapan metode SPK seperti AHP membutuhkan desain tampilan yang memumpuni untuk mendapatkan kebergunaan atau kepuasan pengguna sistem yang sangat baik.

\section{REFERENSI}

[1] Putu Roy Nurbhawa, I Ketut Gede Darma Putra dan Nyoman Gunantara,“ Sistem Pendukung Keputusan Untuk Penentuan Lokasi BTS PT. Smartfren Menggunakan Metode Fuzzy-AHP," Majalah Ilmiah Teknologi Elektro, vol. 16, no. 03, pp.19-26, September Desember 2017.

[2] Yusuf, M, A. 2011. Factors Affecting Consumers Buy Cards In Prime. Jawa Depok Barat.

[3] Gede Ogiana, Ni Made Ary Esta Dewi Wirastuti dan Wayan Gede Ariastina," Group Decision Support System (GDSS) Untuk Evaluasi Penawaran Pekerjaan Konstruksi Menggunakan Metode AHP dan Borda," Majalah Ilmiah Teknologi Elektro, vol. 16, no. 03, pp.19-26, September - Desember 2017.

[4] Yudhamanik Kusuma, Linawati, dan Made Sudarma,“ Penentuan Pemanfaatan Aset Tanah Pemerintah Daerah dengan Sistem Informasi Geografis dan Metode Analitycal Hierarchy Process : Studi Kasus Pemprov Bali”, Majalah Ilmiah Teknologi Elektro, vol. 16, no. 03, pp.19-26, September - Desember 2017

[5] Cindy. 2012. Pengujian Web Aplikasi DSS Berdasarkan pada Aspek Usability. Manado

[6] Turban. 2005. Decision Support System and Expert System. Yogyakarta: Penerbit Andi.

[7] Kevin. 2012. Rekayasa Gui Untuk Remastering Distro Ubuntu Berbasis Aplikasi Customizer. Yogyakarta : Universitas Sanata Dharma 